University of Nebraska - Lincoln

DigitalCommons@University of Nebraska - Lincoln

Faculty Publications from the Harold W. Manter Laboratory of Parasitology

1990

\title{
Dr. Benjamin (Ben) Goodwin Chitwood
}

William F. Mai

Cornell University

Armand Maggenti

University of California - Davis

Follow this and additional works at: https://digitalcommons.unl.edu/parasitologyfacpubs

Part of the Parasitology Commons

Mai, William F. and Maggenti, Armand, "Dr. Benjamin (Ben) Goodwin Chitwood" (1990). Faculty

Publications from the Harold W. Manter Laboratory of Parasitology. 612.

https://digitalcommons.unl.edu/parasitologyfacpubs/612

This Article is brought to you for free and open access by the Parasitology, Harold W. Manter Laboratory of at DigitalCommons@University of Nebraska - Lincoln. It has been accepted for inclusion in Faculty Publications from the Harold W. Manter Laboratory of Parasitology by an authorized administrator of DigitalCommons@University of Nebraska - Lincoln. 


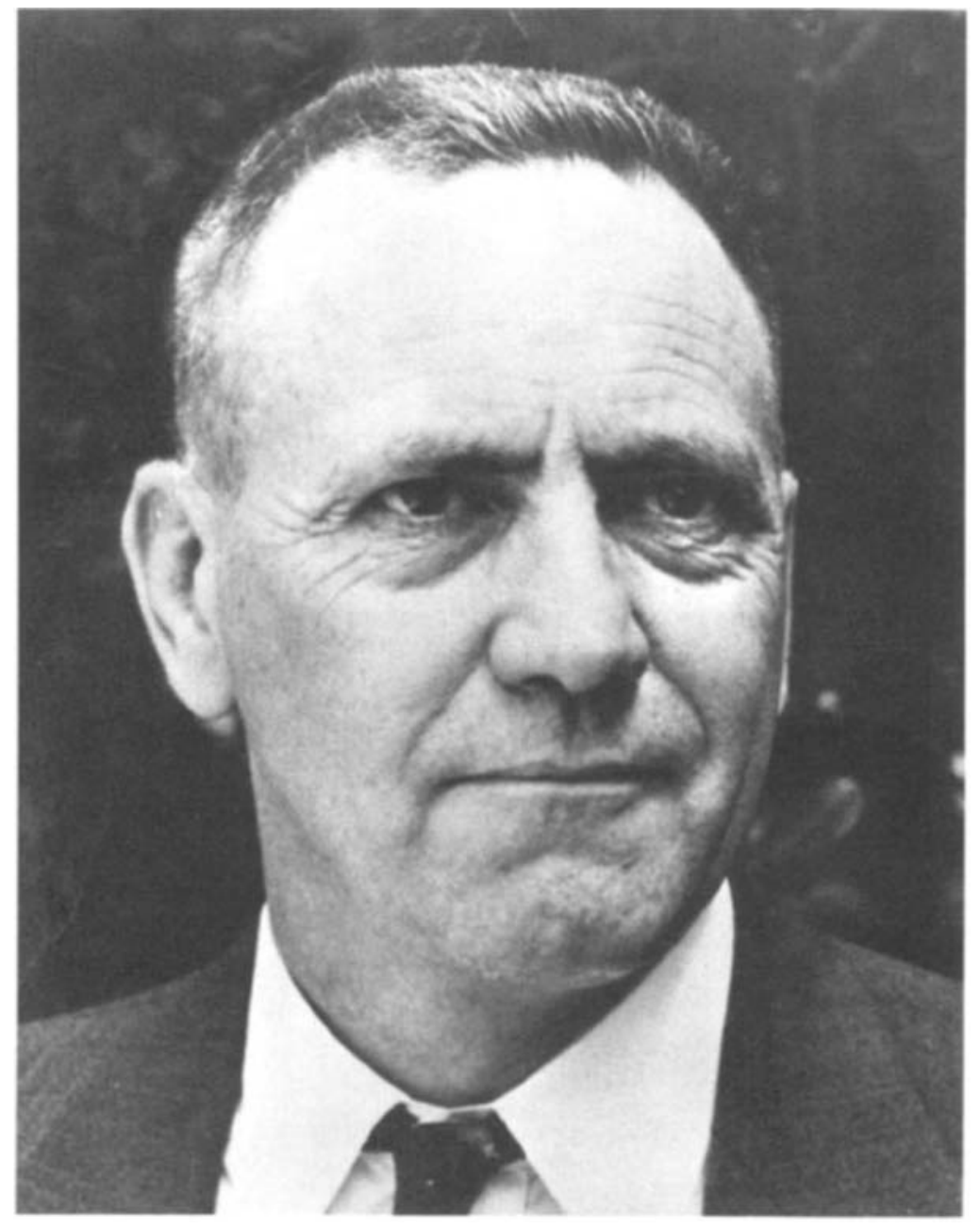

B. G. CHITWOOD 


\title{
DR. BENJAMIN (BEN) GOODWIN CHITWOOD
}

\author{
William F. Mai
}

Department of Plant Pathology, Cornell University, 334 Plant Science Building, Ithaca, New York 14853

\section{Armand R. Maggenti}

Department of Nematology, University of California, Davis, California 95616

KEY WORDS: history nematology, history USDA, biography, nematology, systematics

\section{THE EARLY YEARS}

B. G. Chitwood was born in Chicago, Illinois, on December 21, 1907 and died November 19, 1972. During the sixty-four years of his life he became the most influential nematologist of this generation. His influence will continue for generations to come. It is highly improbable that any one person will ever again be able to duplicate his extensive knowledge and understanding of the phylum Nemata.

If one word had to be chosen to describe Dr. Chitwood we would be at a loss; the word could be dedicated, or relentless, or inexhaustible, but never inflexible, or narrow-minded, or vindictive. He had no patience with stupidity but great compassion for the ignorant and he did make the distinction, much to the chagrin of some colleagues.

Ben enrolled in Rice Institute in Houston, Texas, at the age of sixteen, as a pre-medical student. However, prior to official entrance he had studied general zoology by correspondence from the University of Chicago under Professor H. H. Newman and biology and botany from San Marcos Baptist Academy. During his college career he discovered that his primary interests were in evolutionary relationships and systematics.

$0066-4286 / 90 / 0901-0013 \$ 02.00$ 
His introduction to nematodes came when he was a senior undergraduate working with guinea pigs in the Animal Shed at Rice Institute. He discovered what he thought was a new species of nematode. He described the species and reported on the histologic morphology of the female reproductive system. Upon completion and illustration of the manuscript he sent it to Dr. N. A. Cobb. Cobb confirmed Chitwood's findings (Chitwood later discovered that they were both wrong as to the newness of the species); nevertheless, Chitwood had been introduced to the world of nematode systematics and morphology - a field to which he devoted much of his life.

Upon graduation in 1928, Chitwood was hired by Cobb (June 15, 1928) as a Junior Nematologist. His assignment was to assist Dr. J. R. Christie in his investigations on mermithids as potential biological control agents of grasshoppers. Chitwood's desire was to work with Cobb on marine nematodes. To pursue this interest in marine nematodes he worked after hours for Cobb preparing permanent slides and morphological sections.

While employed in the Division of Technology and Nematology of the Bureau of Plant Industry in the United States Department of Agriculture (USDA) he entered into a Master of Science program under the directorship of Dr. P. Bartsch at George Washington University. The degree was conferred in 1929. Chitwood immediately proceeded towards the $\mathrm{PhD}$, again under Bartsch, which he received two years later in 1931 at the age of 23 , with a thesis entitled The Role of Nematodes in Strawberry Diseases. Thus was set the hectic lifestyle that was to follow him to his death.

It is a tribute to his genius that he could handle numerous diverse activities and do them all well. In the seven years from 1924 to 1931 he completed his baccalaureate, ran on his collegiate long-distance team, entered the 1928 Olympic trials, married May Belle Hutson (April 17, 1927), published his first paper in Nematology (by the end of 1931 he had published more than a dozen papers on nematodes), accepted a full-time position at the USDA, earned his Masters and $\mathrm{PhD}$ degrees, and worked after hours preparing slides for Cobb.

In 1931 Chitwood transferred to the Zoological Section of the Bureau of Plant Industry, where he held a position as zoologist until 1937. During these years he published more than 70 papers. This was a time of learning, exploration, and experimentation. It was in this position under the tutelage of Dr. Maurice Hall that he first began to think about nematode higher classification. Later he took over Hall's project on the Classification of the Nematoda. It is unlikely that he could have produced An Introduction to Nematology had it not been for the experience gained during his years in the Zoological Section.

His duties as a zoologist provided Chitwood with the opportunity to study nematodes with broad license. His investigations, though largely restricted to 
nematode parasites of vertebrate and invertebrate animals, dealt with nematode systematics, morphology, biochemistry, and physiology. Morphological emphasis was placed on head structures, esophagi, the nervous system, and somatic musculature.

The broad latitude of the zoology position and his involvement in Hall's project allowed Chitwood an opportunity to study marine nematodes. Of all the nematode taxa he investigated, it seems that he derived the greatest pleasure from his marine nematode studies. In 1934 he published a paper on two new species of marine nematodes from the Puerto Rican deep and in 1936 he published on the marine nematodes from the North Carolina shores and a third paper was devoted to the marine Enoploidea.

In the midst of his near total immersion in work, he maintained appreciable skill as a long-distance runner, served as vice-president of the Helminthological Society of Washington in 1937, and found time to begin his collaboration after hours with his wife, May Belle, on the production of An Introduction to Nematology. During this period they maintained a complete laboratory with microscopes, a microtome, and other essential equipment in their home where they worked evenings, weekends, and vacations. May Belle became a noted nematologist and histologist in her own right.

In 1937 Chitwood returned to the Bureau of Plant Industry under the directorship of Dr. G. Steiner and was immediately transferred to Long Island, New York, where he conducted research on nematode diseases of ornamental plants. He remained on Long Island until 1947. The decade spent on Long Island was not as productive in numbers of publications as his preceding tenure as a zoologist. However, it was the period of his greatest contribution to the science of nematology. In 1937, Chitwood and his wife released Section I, part 1, of An Introduction to Nematology; this was followed in 1938 by Section I, part 2, in 1940, with Section II, part I and, finally, in 1941 Section II, part 2. These publications are testimony to his photographic memory and remarkable ability to synthesize the information he retained. If his genius was not recognized before, the world of nematology and invertebrate zoology certainly became aware of it with the release of the Introduction. Upon examining this publication for the first time, a beginning student remarked, "If this is just an introduction, nematology is indeed a complicated and difficult subject." This observation is true for there has never been a more comprehensive publication on this subject.

The importance of the Introduction to the development of the science of nematology cannot be overemphasized. It was a valuable reference when published and it is just as valuable today. No longer was information scattered helter-skelter throughout the literature and only available to specialists. The then-known information had been put in one place and, perhaps more importantly, synthesized. This magnificent contribution opened the door to the 
learning and teaching of nematology in many institutions in the United States and abroad. Prior to the publication of this book, teaching was on a one-toone basis and confined to the observational limitations of the teacher. The Introduction also gave us the first comprehensive higher classification of nematodes.

Cobb proposed in 1919 that nematodes should be recognized as a phylum Nemata (=Nemates). Though Chitwood would have preferred phylum Nemata as the designation, he called it Nematoda (using the old class name), a misjudgment he acknowledged and corrected in 1958. Another important taxonomic step was the division of the phylum into two classes: Adenophorea (=Aphasmidia) and Secernentea (=Phasmidia). Chitwood in 1937 wanted to use Adenophorea and Secernentea but because of prejudices in many quarters against Von Linstow, he allowed administrative pressures to prevail and used Aphasmidia and Phasmidia; this too he rectified in 1958. Dr. E. C. Dougherty is credited with the revival of "Secernentea" but the entire proposal rightfully belonged to Chitwood. Dougherty "inadvertently" published "Secernentea" prior to the release of Chitwood's paper.

Filip'ev in 1934 commented that if classes could be defined within the nematodes he would accept Cobb's proposal of phylum status; Chitwood did define the classes and they as well as the phylum are still recognized in invertebrate zoology after fifty-two years.

Chitwood's assignment to Long Island might be attributed to the fact that his $\mathrm{PhD}$ dissertation, in part, was concerned with Ditylenchus dipsaci. At the time of Chitwood's transfer, Ditylenchus dipsaci on Long Island was the subject of a rigid quarantine. Such a position was less than desirable for someone as opinionated and argumentative as Chitwood-no one would ever have described him as being diplomatic. Gerald Thorne thought that Chitwood was the victim of bureaucracy and later noted that " . . because of the drastic quarantine regulations forced on the growers, there was bitter opposition and high tensions developed. A fire, thought by some to be incendiary, destroyed the USDA station and among the items lost was Ben's huge manuscript on the genus Rhabditis." The loss of this manuscript was devastating; Chitwood never attempted to redo it. This was a major loss to the science. Its absence has had many repercussions for this group remains to this day much confused and little understood.

One of us (Mai) was stationed on Long Island at this time and remembers the initial golden nematode laboratory as being reminiscent of four garages shoved together.

The situation was not helped by Chitwood identifying Globodera $(=$ Heterodera) rostochiensis as the cause of plant damage in a potato field on Long Island. This nematode, which he dubbed the "golden nematode", also became the subject of a strict federal quarantine. Chitwood may have called it 
"golden" but it proved to be pyrite for him. His work was quite varied during this period: he tested nematicides, put on fumigation demonstrations, developed hot water treatments for bulbs, reported ring nematodes as a possible cause of decline in peach orchards (proven some years later). After hours he still had time for taxonomy, morphology, and publication of the Introduction.

While on Long Island Chitwood also pursued what may have been his favorite hobby, the breeding of champion beagle dogs. And, as with most things he attempted, he was quite successful. He was so successful that a wealthy female competitor, whose dogs were unable to defeat Ben's in shows, became discouraged. As a result, she tried to hire Chitwood to take charge of her beagle breeding program. She offered Ben twice his annual salary but he told her he would rather stay in nematology.

Chitwood achieved his success in beagle breeding without the benefit of professional help or special kennels. His kennel consisted of a converted garage, backyard, and parts of his home. In these limited facilities he often maintained 40 to 50 dogs. Finding suitable protein for this many dogs often proved to be a formidable task for the Chitwood's and the first author's family during the meat rationing of the World War II. The dogs also provided Chitwood with another favorite pastime, hunting. In fact, just prior to his death he was anxious to get his new business affairs in order so that he would be relatively free for the upcoming hunting season.

Chitwood was reassigned to Beltsville in 1947; he was now tired and dejected. In 1949, however, he accepted the presidency of the Helminthological Society of Washington. For twenty years he had been driving his body and mind through superhuman efforts and those exertions began to take their toll. Only sporadically throughout the rest of his life would the energy, drive, and enthusiasm of this genius be evident. The burning of the laboratory on Long Island, the loss of his manuscript (representing years of research), the destruction of his prized microscope, a serious auto accident, and the subsequent divorce from May Belle furthered his despondency and worry; these misfortunes would have destroyed a lesser man.

In the midst of all this turmoil, he produced in 1949 what many think was his second most important contribution, a revision of the taxonomy of rootknot nematodes. Chitwood noted that relative to Heterodera marioni there was conflicting evidence as to behavior and host range. Chitwood wrote, "Recently Christie and Albin (1944), Christie (1946), and Christie and Havis (1948) have established experimentally beyond doubt that we are dealing here with several diverse kinds of nematodes." On the basis of morphology and host range, Chitwood set about distinguishing five species and one variety (currently recognized as a valid species) in the genus Meloidogyne Goeldi, 1887. Chitwood always had a soft spot for "guinea pigs", and the first author, who was also then stationed at the Long Island laboratory, was chosen by 
Chitwood to test whether or not an "inexperienced" nematologist could separate the then-known species of root-knot nematode. The "inexperienced" nematologist admits to having undergone many trials and tribulations in trying to find differences in the swirls, squiggles, lines, dots, etc, of perineal patterns.

Finding that root-knot nematodes constituted a group of pathogens, not one organism, as formerly supposed, changed the research and control strategies for these world-wide economically important nematodes. After Chitwood's publication, in each and every region of the world, studies were required to understand the life, host range, host-parasite interactions, and the environmental relationship of each species of root-knot nematodes.

As with most of Ben's efforts, the approach was innovative; the principle characteristic was found to be differences in perineal patterns. This character is still the principle means used throughout the world to distinguish the nearly one hundred nominal species of root-knot nematodes; however, additional aids to root-knot identification have been added. It was and remains a remarkable paper. This paper was to mark the end of his long and highly successful association with the USDA.

Both Ben and May Belle recovered from their serious auto wreck on Long Island without serious complications. Chitwood excelled in almost everything he tried, with one notable exception, driving. Ben may well have had the distinction of being among the worst drivers ever to sit behind a steering wheel. It was not that he was incompetent; it was his power of concentration. Unfortunately, his concentration was on science and new ideas rather than on the realities of what was happening on the asphalt in front of him. There were two ways to recognize that Chitwood had been in another auto accident: one was to hear he was in the hospital and the other was that he was driving a new car!

The second author was reviewing a manuscript with Chitwood who, at the time, was working at the Kaiser Institute in Richmond, California. So-called friends and colleagues had not warned him of Chitwood's reputation as a driver. They were going to be working late into the night so Chitwood suggested they go out for dinner at his favorite restaurant. (Not fermented coffee and cherry pie, as the first author would remember, or one-half gallon of milk and a gallon of ice cream, as Dr. B. Nickle and Mr. G. Paxman were treated to, but dinner in a restaurant!) Everything seemed relatively normal until Ben made a right turn onto a one-way street going in the wrong direction. Armand mentioned this to Chitwood in a controlled but highpitched voice of panic. Chitwood acknowledged that he was going the wrong way but personal survey had convinced him that this route was not only shorter but also not as heavily traveled as other avenues in the city. Chitwood had the disconcerting habit of looking at the passenger while he talked; 
therefore during this discourse he was looking at Armand and not the road. To this day Armand remains impressed by the defensive driving of the on-coming motorists. The man was oblivious to the danger he created. Chitwood's expressed attitude was " . . . the other drivers don't want to get in a wreck."

\section{THE LAST YEARS}

After his resignation from the USDA Chitwood was hired by the Catholic University of America as an Associate Professor of Parasitology. Fr. R. Timm recalls that in the first class session Chitwood faced about 60 students and commenced lecturing. The subject matter covered about 75 pages of an ordinary textbook. Ben threw out long names right and left without writing anything on the board. The second day of class he began with an oral quiz and, finding almost complete ignorance throughout the class, launched into a minor tirade, "I taught you all this yesterday! Don't you people know any biology?"

The list of students who participated in the course is impressive-Drs. Ben Lownsbery, Charles Tarjan, Bakir Oteifa, Eldon Cairns, Joe Sasser, and Chitwood's graduate students Drs. John Elsea, Bill Uriccho, Jack Owens, and Fr. Richard Timm. All of Chitwood's students whether formal or informal agree that though he was less than spectacular in the classroom, he was exceptional on a one-to-one basis, both in the laboratory and in the field. Although he was an impatient teacher and often became angry with students when they did not meet his standards quickly enough, he worked hard teaching them and gave unlimited amounts of time to them.

Fr. Timm noted, "In our last year at Catholic University (1952), it was obvious that Ben was wearing himself out, but he could never halt or stop his fertile mind from speculating."

After 28 years of near superhuman efforts it was time for Chitwood to stop and regroup. He spent the next few years recuperating, gaining back his health, strength, and energy; he was never as strong as before yet he still had energy and enthusiasm enough for two people. During the period of 1950-55 Chitwood published some 27 papers as well as a revision of Section I of the Introduction. He extended his field of study beyond nematodes and he published on such diverse taxa as Tardigrada and Kinorhyncha.

After leaving Catholic University Chitwood held several minor positions in nematology. In 1955, he was appointed as the first Chief Nematologist of the Florida State Plant Board. He remained in this position until 1958 and played a major role in establishing and developing the Nematology Section of this institution. Chitwood had now truly stepped into the role of administrator. As was his nature, he spent considerable effort teaching those who worked for 


\section{MAI \& MAGGENTI}

him. Although he set high standards for his subordinates and insisted that these standards be met, he was considerate of them, insisting that they receive promotions and taking them to meetings to increase their interest and knowledge of nematology and related sciences.

Chitwood's energy was renewed and he was enthusiastic about this new challenge to develop nematology in Florida. From 1955 to 1958 he published nine refereed papers and several informational bulletins devoted to phytonematology. The refereed papers were mainly taxonomic: a revision of Haliplectus Chitwood, 1956; new species of Xiphinemella Chitwood, 1957; Criconema Chitwood, 1957. In collaboration he published two new genera Meloidodera Chitwood, Hannon and Esser, 1956 and Hemicriconemoides Chitwood and Birchfield, 1957, as well as a redescription of Atylenchus Chitwood and Tarjan, 1957. Esser and he also published on the pathogenicity of Meloidodera on slash pine.

The non-refereed papers were for general understanding and public information. There were talks to growers, inspectors, and the public, stressing the importance of nematodes to Florida agriculture.

Chitwood left the Florida State Board in 1958 and subsequently moved to California where he joined Dr. E. C. Dougherty, who was then director of The Kaiser Research Institute, Laboratory of Comparative Biology. At first they were located on the University of California, Berkeley, (UCB), campus but soon moved to the Kaiser facilities in Richmond, California, about two miles away. For the next three years Chitwood was a frequent visitor to Dr. M. W. Allen's laboratory at UCB. His frequent visits continued even after nematology at UCB was transferred to Davis.

The second author (then a graduate student under M. W. Allen) met Chitwood in 1958. Because Chitwood had been publishing since the late 1920s, his naive expectations were to meet an old, decrepit, outdated scientist who should be respected and allowed to rest on his laurels. Before him stood a vigorous, slightly unkempt man of fifty, who viewed life over half-glasses and responded to small talk as if the conversationalists were ignoramuses.

Armand had anxieties about their first meeting because he knew that the subject of his doctoral dissertation was related to Chitwood's own areas of interest. These anxieties proved to be unwarranted. Ben displayed a genuine interest in Armand's research, questioned him, looked at what he had accomplished, and asked how he had come to a certain, now forgotten, conclusion. Armand remembers answering, "I read the bible." Chitwood looked quizzical and Armand said, "I read your book." Chitwood smiled and said, "So you are the one." This was the beginning of their friendship, his mentorship, and sometimes animosity.

In 1960 Chitwood asked Armand to present the proposal put forth in his thesis before Kaiser's Second International Conference of Invertebrate Zool- 
ogy. Chitwood was fully aware of the fact that many of Armand's concepts concerming nematode higher classification and phylogeny were in opposition to his. This did not disturb Chitwood, rather he was excited by this new, hopefully defensible, concept. Armand prepared and presented what he thought was the completed manuscript for Ben's editing one month before the symposium. During the ensuing month they examined every species mentioned and checked all available literature. Armand maintains that this experience remains among the most memorable, educational, exciting, and rewarding times of his career.

Chitwood was insatiable when new thoughts and ideas were being generated. At two, three, or four in the moming as he made Armand defend every thought he had written, Armand would say, "Doctor Chitwood, I am exhausted and must sleep." Ben's response was invariably, "I don't understand young scientists. If you must sleep, sleep, but be back by 8 o'clock."

Chitwood rarely answered a question about unknown information in nematology; rather, his observation was invariably, "I can give you a thousand answers, all of which are likely to be wrong." However, if you would offer an explanation of an unestablished idea, he would with unending enthusiasm discuss the logic of your conclusions and either reject your findings or become excited as to how this information could be tested. Every avenue available would then be pursued: fresh collections made, literature obtained at any cost, preserved specimens observed, and human endurance tested.

Zeal in solving difficult intellectual puzzles was the essence of Chitwood's character as a scientist. New information always seemed to unlock doors that opened new vistas of thought that added new pieces to the puzzle of nematodes and their relationship to the world of invertebrate zoology. He was the first to admit that the puzzle would not become complete in his lifetime or several others. The purpose was to fit a piece into the puzzle and no piece was to be ignored or through cowardice conservatively placed. Chitwood was never one to solve a puzzle by being content to first form the edge; no, his approach was let those who are conservative form the edge; he would put pieces together as they became known-for that would be the heart of the picture.

The scientist, teacher, and man were seldom seen in totality for Dr. Chitwood was a very private individual and normally only let one, at most two, personality traits be seen at any given time. There was a notable exception-a field trip, especially to the ocean. On such occasions Chitwood was congenial and very good company. He would relate interesting and amusing anecdotes about the scientists he had known and respected; people whom those present only knew through their publications. Fortunate were those who shared these occasions with Chitwood, for all of us they hold many pleasant memories. 
In retrospect, it seems that Dr. Chitwood was entranced by any large body of water where the far shore could not be seen. He was always a leader in his science, often standing alone against the derision of lesser minds, and perhaps he identified with the limitless horizon of the ocean where no foreground object obstructed his view.

The years of 1958, '59, '60 in California were happy ones for Chitwood; he had the ocean and a boat to sail on it. He was free to study nematodes in all aspects: taxonomically, morphologically, biochemically, and embryologically. Few papers were published but many were planned. He wrote Nematoda for the McGraw-Hill Encyclopedia, and Nemata with Allen for Ward \& Whipple's Freshwater Biology. He published on the marine nematodes of Northern California, and began a revision of Kinorhyncha. He traveled to Guatemali to study possible control strategies for root-knot nematode on coffee. In 1959 and 1960 he helped to organize Kaiser's two international symposia on biology, the first on the comparative biochemistry of photoreactive pigments and the second on comparative biology and phylogeny of the lower metazoa. Both were highly successful and attracted scientists from around the world.

E. C. Dougherty left the directorship of Kaiser's Research Institute in 1960 but Chitwood remained until 1961. Following Dougherty's departure, Kaiser Research Institute made a decision to place future priorities on the gnotobiotic culturing of Caenorhabditis briggsae. Chitwood's project, which was devoted to the taxonomy, morphology, and rearing of marine nematodes, was assigned the lowest of priorities and, therefore, it was terminated. There were few prospects in nematology on the horizon. His long and prosperous career in nematology was coming to an end.

In 1961 he accepted a temporary position as Senior Pathologist in the Agricultural Experimentation Station of the University of Hawaii. After a short stay in Hawaii, where he married Lily B. Devries (March 2, 1962), he returned to the mainland and settled in the state of Washington. Here for two years he taught biology at Western Washington State College. While at WWSC Chitwood participated in the diplogasterid colloquium held in Florida, November 4-6, 1964. This was his last presentation to the science.

Chitwood began to plan his retirement from science in 1967; he hoped to raise citrus commercially. The untimely death of his third wife Lily ended any desire to fulfill these plans. And, in 1970, Chitwood left Tacoma, Washington and moved to Marquette, Michigan, where he intended to start a florist and nursery business. Never satisfied with being involved in only one endeavor, he was also venturing into commercial fishing on Lake Superior at the time of his death.

Chitwood was indeed quitc a man: tireless, confused, obsessed, brilliant, unhappy, misunderstood-a genius. 


\section{ACKNOWLEDGMENTS}

The authors thank all those who added to this portrait of Dr. Chitwood either through their written eulogies or sharing their experiences with us: J. Christie, R. Esser, C. Hannon, B. Hopper, L. Jacobs, F. Jones, B. Nickle, G. Paxman, A. L. Taylor, G. Thorne, and R. Timm. Our sincere gratitude is extended to all those who shared their Chitwoodian experiences with the authors during the national meetings in Davis, CA, 1989. 